\title{
EVALUATING EFFICIENCY IN SPECIALIZED HOSPITAL FACILITIES - DEVELOPING THE MODEL BY WAY OF THE DISCRIMINANT ANALYSIS
}

\author{
Stanislav Szabo, Bohuslava Mihalčová, Peter Gallo, \\ Marianna Ivaničková
}

\section{Introduction}

Research of the issue of evaluating the efficiency in specialized hospital facilities in Slovakia is all important and up to date with the following reasons leading the way. The first one is based on the finding that the number of newborns in Slovakia suffering from congenital heart diseases has increased over the recent years, and in the period between 2002 and 2012 annually 451 children at an average are born with this congenital disorder. The incidence of live-born children suffering from congenital heart disease has been steadily increasing since 2009. The second reason is in that the diseases of the circulatory system are rated among the most frequent cause of hospitalization and mortality in Slovakia, as confirmed by the International Classification of Diseases or the ICD (the international equivalent of the Slovak MKCH-10). Accordingly, people suffering from cardio-vascular diseases belong to the most-frequently hospitalized patients. The third finding we have arrived at is the high level of consumption of prescription medicines by the Anatomical Therapeutic Chemical (ATC) Classification, again dominated by cardiovascular diseases.

Chapter one is devoted to theoretical starting-points focused on the isssue of the public health, describing the efficiency and financing of the public health system. The paper is priamrily aimed at cardiovascular diseases, also defined in chapter one. Covered in chapter two is the methodological part defining efficiency of selected health resorts as objects of research, and as the subjects three specialized hospital facilities health resorts in Slovakia have been chosen by us. Also contained in the methodological part is the description of the selected methods and models applied when determining efficiency in selected subjects of research. The third part is focused on the results of our research based on the numerical data obtained from the subjects of investigation. The data are analyzed using the separate methods and the discussion is about suggesting a model that can be applied in specialized hospital facilities for the purpose of evaluating their efficiency.

\section{Efficiency in the Health Care System}

The notion of health sector efficiency - and related issues such as cost-effectiveness and value for money-are some of the most discussed dimensions of health care performance. These concepts seek to capture the extent to which the inputs to the health system, in the form of expenditure and other resources, are used to secure valued health system goals. In many other sectors of the economy, consumer preferences help to ensure that the most valued outputs are produced at market prices. However, there are numerous, well-rehearsed market failures in the health sector that mean that traditional market mechanisms cannot work, allowing poor quality or inappropriate care to persist at high prices if no policy action is taken. Most commentators would therefore agree that the pursuit of efficiency should be a central objective of policymakers and managers, and to that end better instruments for measuring and understanding efficiency are urgently needed (Cylus, Papanicolas, \& Smith, 2016). The notion of the health system is understood as a sum of activities, measures and facilities serving to protect health, known to be typical for emphasizing prevention against developing and spreading diseases, restraining its occurrence by way of improving our health 
by taking care of the living and working environment, state supervision and leading a healthy way of life (Tesař \& Foltán, 2006). An important role of the public health system is both administer and organize health care provided to all entirely dependent on that kind of services. Health care is offered by both state-owned and private health resorts, in accordance with their specialty and level of material and technical equipment. When characterizing health care (Pažitný, 2014), we can state that even if the health care is surrounded by the scenery of modern technology and architecture, it is primarily a service based on personal interaction between the patient and the medical assistant. Success in providing health care does not only depend on modernization of the health resort and its technology, but to a great extent also on the management, organization of activities, company culture, professional level of its employees, that is to say on the medical staff.

What is a health economic evaluation? A widely accepted definition of economic evaluation has been given by Drummond M.F. and his co-authors: Economic evaluation is the comparative analysis of alternative courses of action in terms of both their costs and consequences (Drummond, Sculpher, Claxton, Stoddart, \& Torrance, 2015).

By (Jönsson, 2004), economic evaluation is a tool to assist those responsible (governments, clinicians, administrators) in making rational decisions about new medical interventions, trying to understand what gives good value for money in the health service. Another definition is done by (Hiligsmann, 2010), who declares that health economic evaluation is a method of evaluating the value for money in medical technologies by comparing alternative options in terms of their costs and consequences. In some definitions, the same idea is expressed make use of the concept of economic efficiency. For example, according to (Miller, 2009), economic evaluation of health care programmes aims to aid decision-makers with their difficult choices in allocating health care resources, setting priorities and moulding health policy. But it might be argued that this is only an intermediate objective. The real purpose of doing economic evaluation is to improve efficiency: the way inputs (money, labour, capital etc.) can be converted into outputs (saving life, health gain, improving quality of life, etc.).
Quoted in (Filko, Mach, \& Zajíček, 2012), are authors of a study investigating the efficiency of Slovak Health Care System. Based on the results obtained, they state that due to the inefficiency of the health care system lifeexpectancy of the inhabitants of Slovakia and Hungary is shorter by 3 years than that in the Czech Republic and 2 years shorter than the average documented in highly developed countries. Among the OECD countries involved in the monitoring, the Slovak Health Care System has recorded the largest setback between the years of 1997 and 2010.

The same conclusions had been arrived at by (Tunega, 2013), who in his study states that the results achieved by the Slovak Health Care System between 2006 and 2010 were worse that it has been appropriate to the available means and inputs. The author also concludes that it is either really so, or the explanatory variables are unable to fairly express the different conditions existing in the countries. With reference to the research (Dlouhý, 2016), the Czech Republic has the best performing health care within the Visegrad countries, whith Hungary with the poorest one. As for Poland, the indicators based on private opinions, population is suggesting worse performance in health care than given by more obejctively oriented indicators. Poles appear to view their health care too negatively when compared to its real level of performance.

The collection of methods used to evaluate efficiency in selected specialized hospital facilities will be presented in the methodological part.

\subsection{Financing the Health System and Health Care}

Healthcare has limited sources and consequently, the total demand of healthcare may not be met (Soltes \& Gavurova, 2015). By (Balík, 2013), financing is a mechanism by which health policiy plans are translated into action through the allocation of resources.

Financing the health care system is a complex mechanism within which the supply side is occupied by providers of health care involving hospitals, medical staff, while on the demand side there are consumers of health care services also referred to as patients (Balík, 2012).

The Constitution of the Slovak republic guarantees every citizen access to a universal 
package of health care free of charge, covered by the public health insurance. In Slovakia there is a compulsory system of health insurance in force, consequently, every citizen is to be insured in terms of health. In Slovakia, a compulsory public health insurance system replaced the tax-financed system in 1994. Compulsory health insurance is administered by one public and two private health insurance companies. All of them are joint-stock companies. The health insurance system is dominated by the publicly owned General Health Insurance Company (Všeobecná zdravotná poist'ovňa), which enrolled $66.5 \%$ of the population in 2010. Persons without income do not pay insurance contributions. It is the government that pays contributions for each such person from the state budget. Health services are generally free of charge but there are some exceptions e.g. supplementary payments for dental services, prescription drugs and emergency services. Health insurance companies collect premiums and purchase the services from the providers. The contribution rate is $14 \%$ of the gross salary from which the employee pays $4 \%$ and the employer $10 \%$. The self-employed pay $14 \%$ of their income base with some additional specific arrangements, which in turn significantly lower the amount paid by them. Persons without income (children, students, the unemployed, pensioners) do not pay any insurance contributions (Dlouhý \& Barták, 2013). Despite significant legislative support of Ministry of Health, support of health insurance companies, as well as other actors of the healthcare system, there is no recorded positive progress in Slovakia in recent years. This relates to the incorrect setting of policy of financing of performances determined by the pricing of health insurance companies influenced by the form of ownership (state vs. two private) (Soltes \& Gavurova, 2014).

In general, health spending in OECD (Organisation for Economic Co-operation and Development) countries grew on average by close to $5 \%$ year-on-year from 2000 to 2009 ; this has since been followed by a sluggish growth of around $0.5 \%$ in 2010 and 2011. Current expenditure on health (i.e. excluding capital expenditure) grew by $0.7 \%$ in both years (Ivlev, Kneppo, \& Barták, 2014).

Unless there is a change in the health policy, according to a basic scenario the deficit of resources in the health system will rise till
2060 to $2 \%$ GDP, or according to optimistic/ pessimistic scenario to $1.7 \% / 2.6 \%$. This has been confirmed by the forecasts of health system public expenses till 2060 (Tesař \& Foltán, 2006) as well as by the Council for Budget Responsibility. However, the income will not cover approximately $22-31 \%$ of public expenses to health system. Therefore, it is inevitable to search for options of increasing health system efficiency by revising the allowances and completing the additional income.

\subsection{Health Care Oriented on Cardio- Vascular Deseases}

By Kamenský (2007), the system of cardiological health care can be divided into areas, concretely as follows: primary and secondary prevention, specialized ambulant care, acute care prior to hospitalization, institutional care and spa treatment.

The authors also maintain that cardiology is an independent specialized branch engaged in epidemology of cardio-vascular deseases as well as diagnostics, prognostical stratification and treatment of cardio-vascular system related ailments etc. For the health care to be provided efficiently and effectively, it is inevitable to ensure keeping records of the patients along with the medical procedures and treatments carried out.

Specialized hospital facilities (further only SHF) focused on the treatment of cardiacand blood vessel-related treatments are independent legal entities and are regarded as end-point places of cardiological work. As stated by (Jönsson, 2004), these facilities ensure a more comprehensive diagnostics and treatment of cardio-vascular diseases.

As by the summary developed by (Nichols et al., 2012), the findings related to the cardiovascular diseases within Euruope and the European Union are as follows:

- cardio-vascular diseases cause $47 \%$ of all deaths in Europe and $40 \%$ within the European Union,

- in most of the European countries, mortality due to cardio-vascular diseases is gradually decreasing, yet still rated as the most frequent cause of deaths,

- annually, cardio-vascular deiseases are causes to more than 4 millions of deaths in Europe and over 1.9 millions of deaths in the European Union, 
- mortality due to ischemic disease of the heart and that of the blood-vessel, apoplexy is higher in the Central Europe than in the Northern or Western Europe.

As figured out by the European Union, the costs of cardio-vascular diseases amount to almost 196 billions of Euro, of which approximately:

- $54 \%$ of costs are attributed to health care,

- $24 \%$ of costs to cover losses in productivity,

- $22 \%$ of costs resulting from informal care provided for people suffering from cardiovascular diseases.

Comparing the cost of treatment in patients with myocardial infarction in the Czech Republic and abroad, we can find that they are much higher abroad than in the Czech Republic (Baustein, Bartak, Janota, \& Rogalewicz, 2015).

As by the information of the National Centre, annualy 205 Slovaks of 100,000 inhabitants die of cardio-vascular diseases, which affect as much as the third of the total number of population in Slovakia. The ratio is steeply climbing, all that at relatively at early time of life. Starting from with some $10 \%$ of people between $20-24$ of age increasening to $31 \%$ at population of $40-44$, to as high as $55 \%$ (50-54 years of age), $76 \%$ in $60-64$ years of age until reaching $90 \%$ of those over seventy. The information was published by the INEKO agency in its latest analysis of the public health status. As much as nine of ten Slovaks suffer from a minimum of one of the risk-factors responsible for the inccurrence of some kind of cardio-vascular diseases. Rated among the major constituents are smoking, lack of physical activities, over-weight and obesity, high cholesterol or improper way of life, in general. The categories of Slovak men suffering from cardio-vascular diseases are: 28 men between age of 0-39 years, 268 men between age of 40-49 years, 1,176 men between age of 50 59 years, 1,352 men between age of $60-69$ years, 2,796 men between age of $70-79$ years and 1,215 men over 80 years. It means 15,477 men with cardio-vascular diseases in total. The categories of Slovak women suffering from cardio-vascular diseases: 8 women between age of 0-39 years, 39 women between age of 40-49 years, 233 women between age of 50-59 years, 829 women between age of $60-69$ years, 1,743 women between age of 70-79 years and 5,732 women over 80 years. It means 8,588 women with cardio-vascular diseases in total.
The worst results were observed in the Eastern Slovakia and the best were associated with the Western Slovakia. This likely relates to declining living standards away from East to the West (Gavurová \& Šoltés, 2016).

\section{The Methodology of Evaluating the Efficiency of Specialized Hospital Facilities}

The object of investigation was to evaluate the efficiency of specialized hospital facilities.

The subject of investigation are the highly specialized hospital facilities active on the territory of the Slovak republic focused on cardiovascular diseases. Concretely, we concentrated on the following special institutions:

- Národný ústav srdcových a cievnych chorôb, a.s. v Bratislave (National Institute of Cardio-vascular Diseases, j.s.c. Bratislava,) slov. abbr: NúSCH, a.s.

- Stredoslovenský ústav srdcových a cievnych chorôb, a.s. v Banskej Bystrici, (Central-Slovakian Institute of Cardiovascular Diseases j.s.c. Banská Bystrica), slov. abbr.: SÚSCCH, a.s.

- Východoslovenský ústav srdcových a cievnych chorôb, a.s. v Košiciach (East-Slovakian Institute of Cardio-vascular Diseases j.s.c. Košice.) slov. abbr.: VúSCH, a.s.

The institutes specialized in cardio-vascular diseases residing in Bratislava, Banská Bystrica and Košice are legal entities called joint stock companies (abbr.: j.s.c.) in which $100 \%$ of the stocks is owned by the state and recently have achieved fair clinical and economical results. The main causes of transformation of these state-owned SHFs were both economic inefficiency and poor efficiency in medical treatment as well. Transformation helped change this status and during the following year, in 2006, things have changed, and as by (VÚSCH, 2015), we have now in Slovakia internationally recognized cardio-vascular centres with top-level professionals, modern equipment and active science and research programmes. The contribution was aimed to analyze the given issue covering the period between 2009 and 2014. Starting with 2009, health care has been provided in new buildings and facilities at the SÚSCCH, a.s. and VúSCH, a.s. Since 01.01.2009 the NÚSCH, a.s. has embraced the Cardio-centre for Children in Bratislava, thereby covering the entire age spectrum of the patients. 
All the three specialized hospital facilities are joint stock companies, thus retaining the homogenity in their legal forms. Over the preiods investigated, they were providing health care for patients suffering from cardio-vascular diseases living in any part of Slovakia, all that offered in modernized facilities.

Both input and output variables have been obtained from the financial reports of specialized heatlh resorts. When identifying them, we have employed descriptive statistics, where, in via the numerical characteristics of the data set, we performed an analysis of the development for the following inputs and outputs: number of employees, number of beds, costs of material, costs of personnel, number of outpatient attendance, number of hospitalizations, number of operations, revenue from selling services and net profit after taxation.

Comparing the development of the input and output variables mentioned as above we went on to analyze the development of the
SHRs. The variables explained have been subsequently used for the evaluation of the technical efficiency applying the DEA method along with other methods of research.

Among the input variables of evaluating efficiency using the DEA method were the number of employees (physicians, nurses, medical assistants, pharmacists, physiotherapists and other staff), number of beds, costs of material (consumption of material, energy and freight deliveries) and costs of personnel (wages, rewards for the members of the decision-making bodies, payments into funds of social security and social benefits). As output variable using the DEA method, selection fell on variables such as number of outpatient's attendance, number of hospitalizations and number of operations. Similar issue using the DEA method was designed by (Khushalania \& Ozcanb, 2017).

Within the framework of evaluating the financial position of the health resorts we

Tab. 1: Comparision of the results obtained by the DEA method

\begin{tabular}{|c|c|c|c|c|c|c|}
\hline \multicolumn{7}{|c|}{ Model BCC Input } \\
\hline SHR/Year & & $\begin{array}{c}\text { Number } \\
\text { of employees }\end{array}$ & \multicolumn{2}{|c|}{ Number of beds } & \multicolumn{2}{|r|}{ Costs of personnel } \\
\hline \multirow{2}{*}{ VÚSCH a.s. } & 2011 & $-3.45 \%(-17.8)$ & \multicolumn{2}{|c|}{$-10.69 \%(-18.9)$} & \multicolumn{2}{|c|}{$-1.13 \%(-108,635$ EUR) } \\
\hline & 2013 & $-3.03 \%(-17.9)$ & \multicolumn{2}{|l|}{-} & \multicolumn{2}{|c|}{$-6.52 \%(-803,861$ EUR) } \\
\hline \multicolumn{7}{|c|}{ Model CCR Input } \\
\hline SHR/Year & & $\begin{array}{c}\text { Number } \\
\text { of employees }\end{array}$ & $\begin{array}{l}\text { Number } \\
\text { of beds }\end{array}$ & \multicolumn{2}{|c|}{$\begin{array}{c}\text { Costs } \\
\text { of Material }\end{array}$} & Costs of Personnel \\
\hline NÚSCH a.s. & 2013 & $-0.87 \%(-8,2)$ & - & \multicolumn{2}{|c|}{-} & $\begin{array}{c}-0.53 \% \\
(-112,725.5 €)\end{array}$ \\
\hline \multirow{3}{*}{ VÚSCH a.s. } & 2010 & $-2.46 \%(-12.5)$ & $-6.83 \%(-11.8)$ & \multicolumn{2}{|c|}{$\begin{array}{c}-4.14 \% \\
-1189,165 €)\end{array}$} & - \\
\hline & 2011 & $-2.53 \%(-13.1)$ & $-10.04 \%(-17.8)$ & \multicolumn{2}{|c|}{-} & - \\
\hline & 2013 & $-2.75 \%(-16.3)$ & - & \multicolumn{2}{|c|}{ - } & $\begin{array}{c}-6.34 \% \\
(-782,392 €)\end{array}$ \\
\hline \multicolumn{7}{|c|}{ Model BCC Output } \\
\hline SHR/Year & & \multicolumn{2}{|c|}{ Outpatient attendance } & \multicolumn{3}{|c|}{ Operations carried out } \\
\hline VÚSCH a.s. & 2013 & \multicolumn{2}{|c|}{-} & \multicolumn{3}{|c|}{$2.26 \%(25.9)$} \\
\hline \multicolumn{7}{|c|}{ Model CCR Output } \\
\hline SHR/Year & & \multicolumn{2}{|c|}{ Outpatient attendance } & \multicolumn{3}{|c|}{ Hospitalizations } \\
\hline NÚSCH a.s. & 2013 & \multicolumn{2}{|c|}{ - } & \multicolumn{3}{|c|}{$0.15 \%(20.6)$} \\
\hline \multirow{2}{*}{ vúsCH a.s. } & 2010 & \multicolumn{2}{|c|}{$13.85 \%(4,950.5)$} & \multicolumn{3}{|r|}{-} \\
\hline & 2011 & \multicolumn{2}{|c|}{$0.35 \%(127.4)$} & \multicolumn{3}{|r|}{ - } \\
\hline
\end{tabular}


obtained financial reports and annual reports for the entire period of investigation, thus providing the data necessary for the assessment of efficiency by way of financial ratios. We focused on a three-balance system.

For us to achieve the goals set, we employed various scientific methods and approaches such as analysis, synthesis, statistical measurement, deduction, comparison and validation, which according to (Lovaš, 2001), represent a process confirming the validity of conclusions drawn from the research. Within the framework of evaluating the efficiency of the specialized health resorts, we have performed comparation of the results obtained by the DEA method, and carryied out evaluations using financial ratios such as liquidity, profitability, activity, and made assessments of the financial position of the SHRs applying predictor models. We were also interested in that if the multi-dimensional prediction models such as the Taffler model, Index IN95, Index IN99 and Index IN05 are suitable for evaluating efficiency of the SHRs under the conditions valid in Slovakia.
By way of a discriminant analysis, we suggested a new model, which appears to be a suitable tool for us when assessing the financial position of the SHRs in question.

\section{Results}

The most frequent method when evaluating the efficency of health resorts is the one of DEA, and we applied it, too. Efficiency and sllippages were calculated using the BCC - input, CCR input, BCC - output and CCR - output model.

By way of comparing the results of assessment in terms of technical efficiency, and employing the BCC and CCR models, we have compiled the following table with the concrete suggestions for changes to achive efficiency. Costs of material and personnel are expressed both in \% and exact values of changes in Euros. The remaining variables were also expressed in $\%$, yielding us the exact number in terms of grossing up or down the input/output variables monitored.

Based on the comparison of technical efficiency assessments and the subsequent

\section{Fig. 1: Development of Immediate Liquidity}

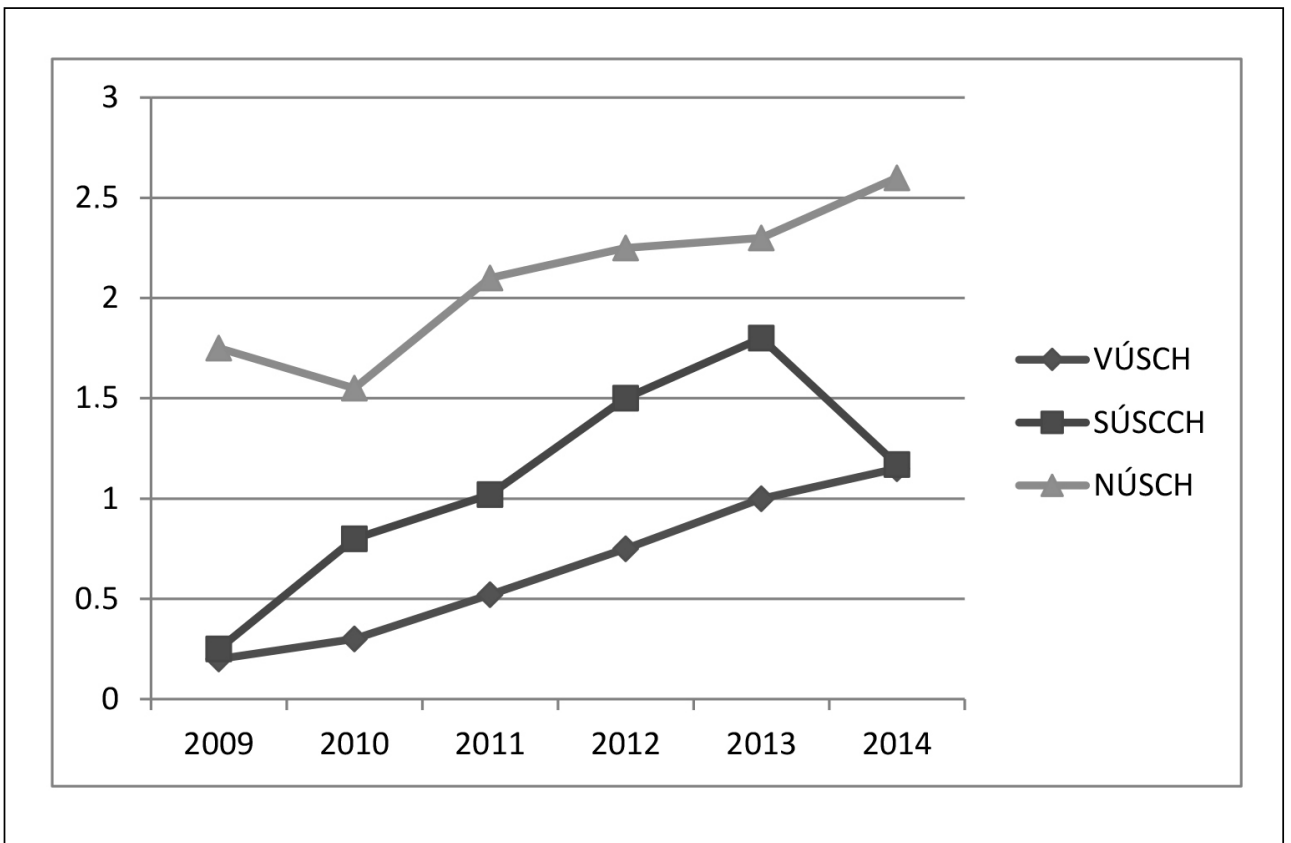


analysis of envolope data, we can state that the most efficient resort of the investigated ones is the SÚSCCH, a.s., minimum inefficiency was recorded in year 2013 at the $\mathrm{NUSSCH}$, a.s. and inefficiency in the years of 2010, 2011 and 2013 was attributed to the last facility, namely the VÚSCH, a.s.

Another method of evaluating effficiency was using indicators of financial ratios. For the purpose of applying them to specialized health resorts, we carried out an objectivization both in time and area. As stated by (Zavarská, 2011), among the important relative indicators of financial performance are those of the profitability, activity and liquidity. It is these financial ratios that we have concentrated on. Comparing the results obtained from the investigated facilities enables us assessing their efficiency by applying financial rations of liquidity, activity and profitability.

\subsection{Indicators of Liquidity}

The indicators of liquidity are informing on the solvency and financial health of the company. Presented in the following three graphs are trends in the development of immediate, current and overall liquidity in the investigated SHRs, namely in the NÚSCH, a.s., SÚSCCH, a.s. and VúSCH, a.s. as well.

The development of Immediate Liquidity, or also termed as 1st level liquidity, see in Fig. 1, is most favourable for the $\mathrm{NUSSCH}$, a.s. achieving the highest values.

The lowest level of Immediate Liquidity was recorded with the VÚSCH, a.s., partticularly in 2009 reaching only 0.18 . Throughout the entire period, the indicator of immediate liquidity in this facility shows a rising tendency, which is considered positive. Further indicators of Liquidity were those of Current- and Overall Liquidity, i.e. L2 a L3, the developments of which are presented in the following figures (Figs. 2 and 3).

The highest value of Overall Liquidity is achieved by the $\mathrm{NUSCH}$, a.s., with the SúsCCH, a.s. as second in order, whereas the lowest indicator of liquidity L3 is obtained by $\mathrm{VUSCH}$, a.s. Comparing the results on the development of the liquidity ratios, we can state that all the three specialized health facilities are demonstrating good solvency over the period investigated.

\section{Fig. 2: Development of Current Liquidity}

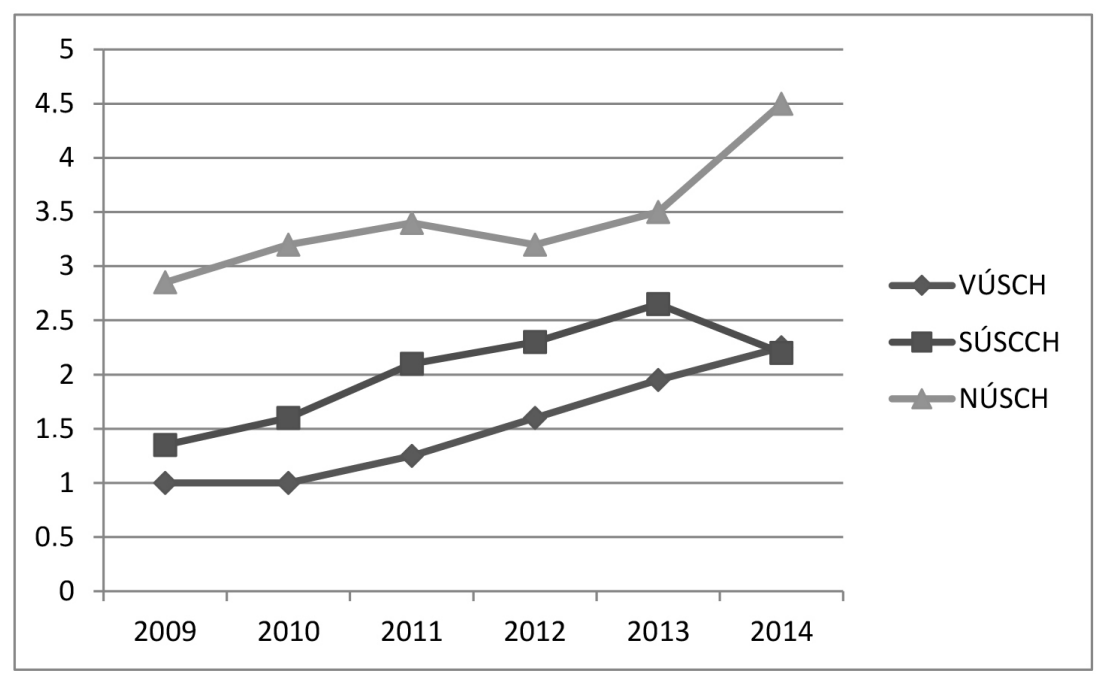



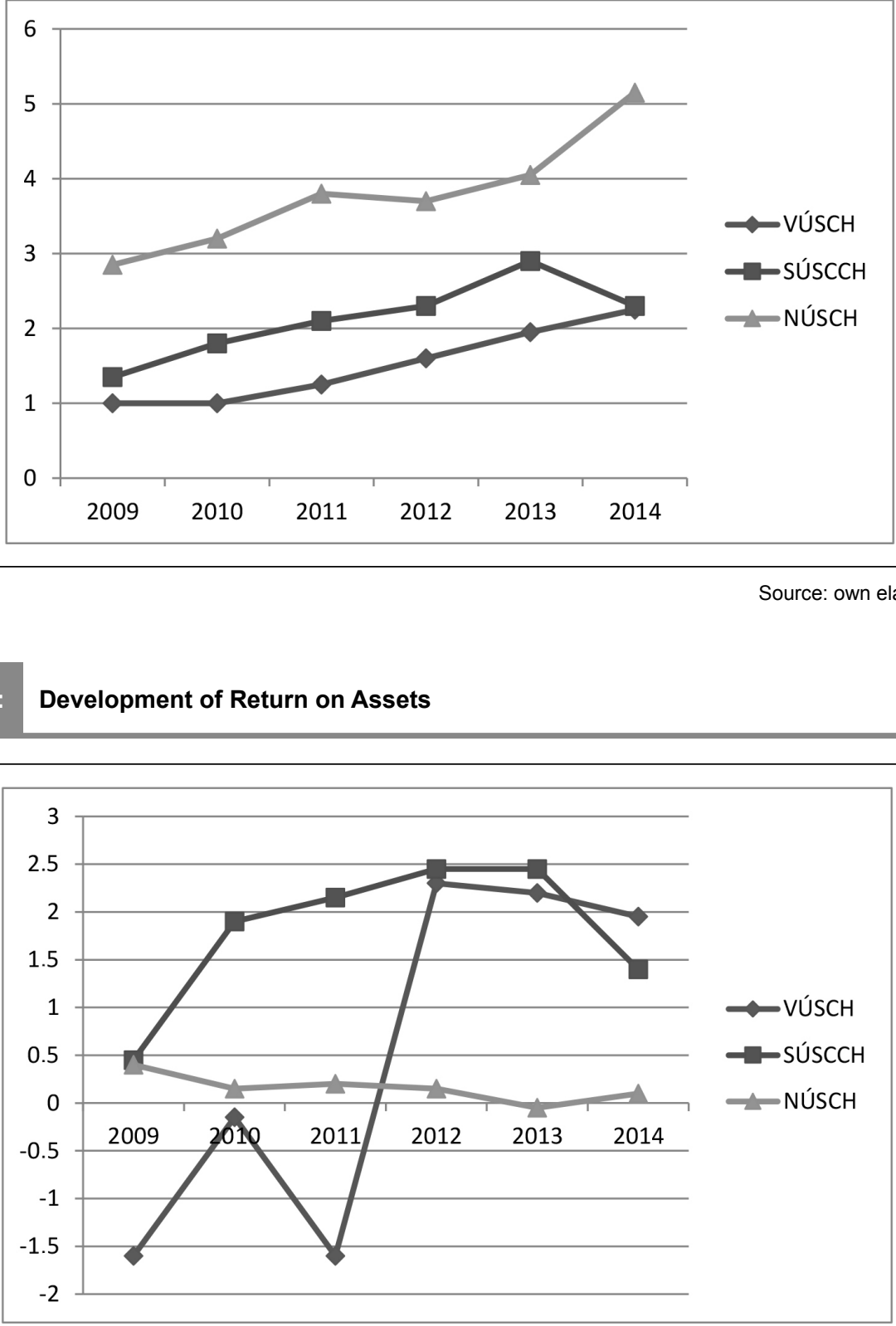


\subsection{Indicators of Profitability}

The development of profitability has been analyzed by way of indicators sucha $s$ the Return on Assets (ROA), Return on Equity (ROE) and Return on Sales (ROS). The indicator is expressing the profitability of the financial assets invested, providing a fair tool of assessing the overall efficiency of the facility.

The first indicator is the one onf Return on Assets to evaluate the efficiency of the SHRs investigated. The results obtained as for the ROA are illustrated in Fig. 4.

Development of the Retun on Assets at the VúSCH, a.s. had its lows in 2009 and 2011, obtaining negative values such as $-1.59 \%$ (2009) and $-1.56 \%$ (2011). Starting with 2012 the ROA indicator in the given facility is experiencing its highest growth, maintaining high and positive values through 2014. The results are pointing out the fact in that the VúSCH, a.s.had failed to make efficient use of its assets untill 2011. However, the situation took a positive turn starting with 2012 with the facility making use of its assets more efficiently. Development of the $\mathrm{ROA}$ at the $\mathrm{NÚSCH}$, a.s. during the investigated period is seen slightly above zero, thereby proving lower level of efficiency in using assets, while demonstrating no substantial changes over the period discussed. The highest values of ROA developments is recorded at the SÚSCCH, a.s., pointing out the fact that it is in this SHR where assets are made of the most efficient use throughout the entire period of investigation.

The second financial indicator of Profitability is the one of Return on Equity, which depends on the level of indebtedness, another important financial indicator, with its development presented in Fig. 5.

Return on Equity expresses the rate of profitability on the capital invested by the stockholders. Based on the results of the analysis, the best situation is at the SÚSCCH, a.s., where the ROE reaches the highest values. The peak value of ROE is as high as $5.25 \%$ for year 2012, a value not exceeded by any of the investigated SHRs over the investigated period of time. Variable behaviour of the Return on Equity is recorded when evaluating the VúSCH, a.s., with the ROE falling into negative numbers until 2011. A steep rise took place in the facility during the next year, namely in

\section{Fig. 5: Development of Return on Equity}

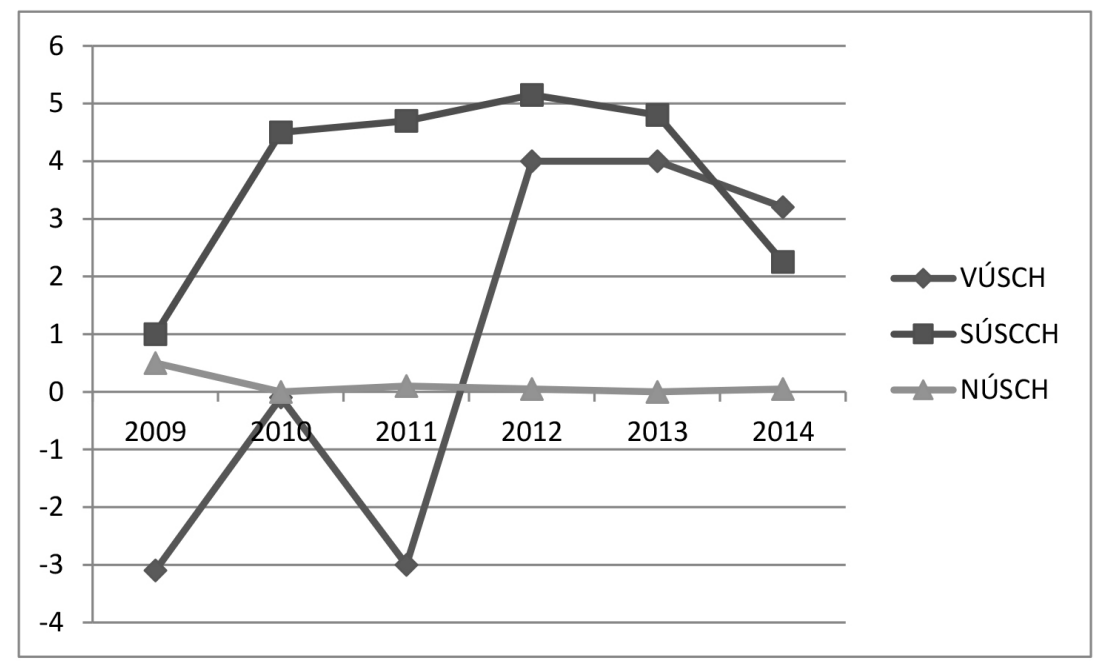




\section{Fig. 6: Development in the Return on Sales}

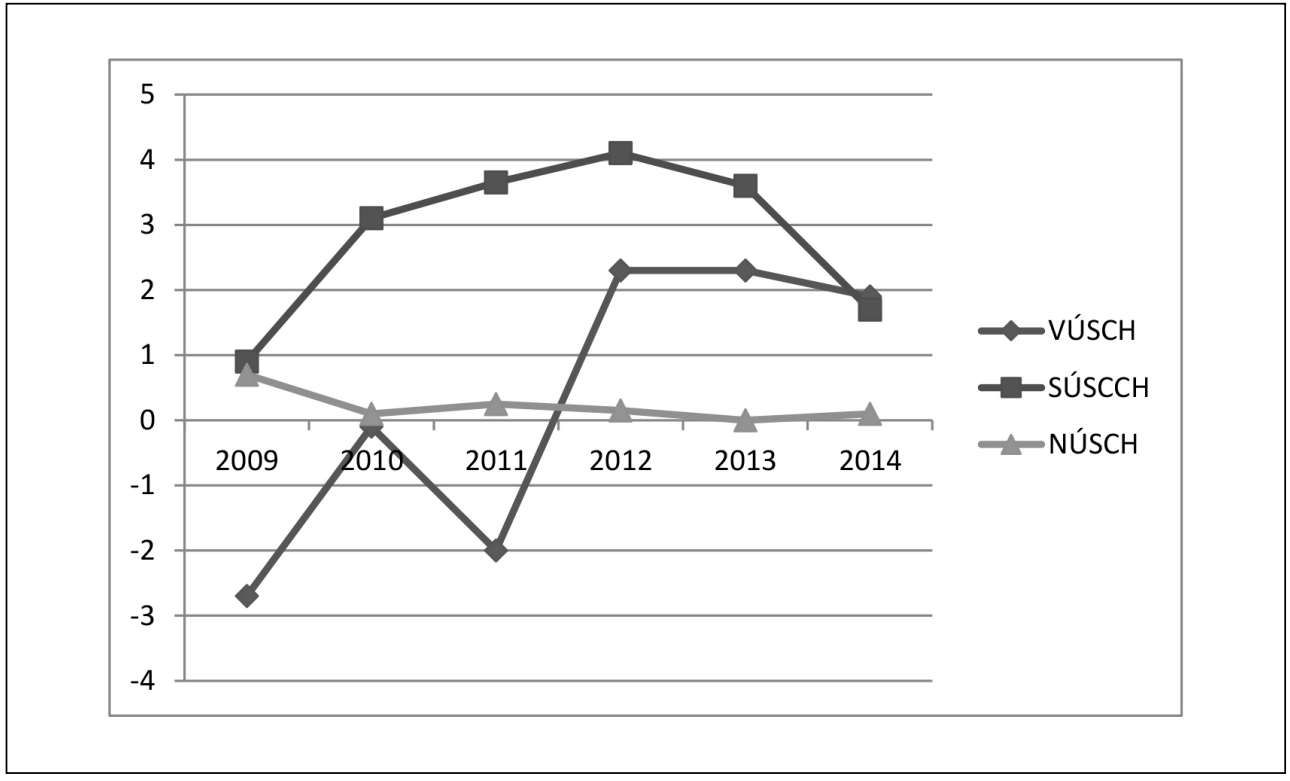

Source: own elaboration

2012, when ROE rose as high as na $4.07 \%$, maintaining positive values over 2013 and 2014. As for the NÚSCH, a.s., Return on Equity is steadily slightly above zero, thus, deserving the worst rating of this indicator from all of the investigated specialized facilities.

The group of profitability indicators is made complete by the last indicator, the one of Return on Sales, developing as seen in Fig. 6. The results reveal the fact that the higher the ROS obtained, the higher the profitability per one euro.

Graphic illustratios of ROA, ROE and ROS are quite similar and comparing them leads us to the conclusion that the SúsCCH, a.s. has proven the best in view of profitability ratios, i.e. being the most efficient SHR. On the other hand, the lowest level of efficiency was recorded at the $\mathrm{NUSCH}$, a.s. and the facility investigated as last, namely the $\mathrm{VúSCH}$, a.s. appears to be inefficient until 2011 and in the year 2012 changes occure and since then on profitability rations keep showing only in positive values.

\subsection{Indicators of Activity}

The last group of indicators fro assessing efficiency by way of finacial rations are those of activity. First, the development of Turnover on Assets is demonstrated as seen in Fig. 7.

The indicator of Turnover on Assets is answering the question, how many times the company assets are turned over 1 year, consequently ideal numbers are those nearing to number 1 . Troughout the investigated period of time the most favoureable development for the TOA is in years 2013 and 2014 at the VúSCH, a.s., where the TOA is in excess of 1. Based on the results we can state that the assets have been best utilized in the SHR mentioned. On the other hand, the lowest TOA over the investigated period is seen with the $\mathrm{NÚSCH}$, a.s., oscillating within the interval between 0.50 to 0.69 . Somewhat higher results as regads the TOA are experienced with the SúsCCH, a.s., found within the interval of 0.50 up to 0.80 . Making use of the total Assets cannot be considered efficient and efficacious, as the value obtained for the TOA neither for the $\mathrm{NUSSCH}$, a.s. nor for the SÚSCCH, a.s. have failed to reached the value of 1 , nor were fluctuating around this value.

The Turnover of Receivables is the second in order financial indicator of activity, with the 
Ekonomika a management

Fig. 7:

Development of Turnover on Assets

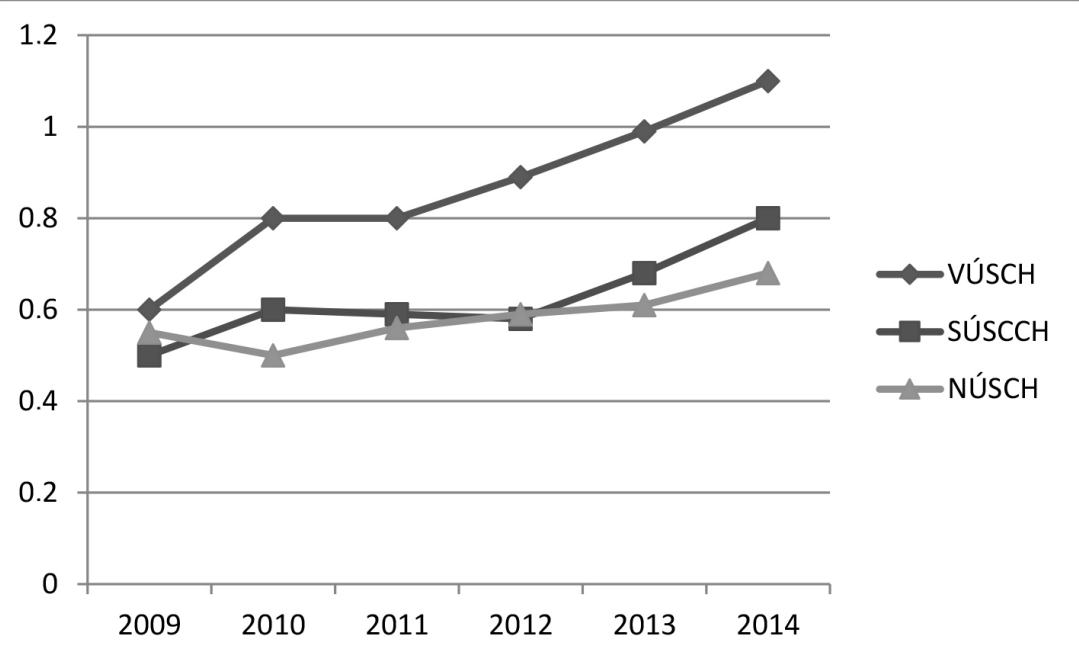

Source: own elaboration

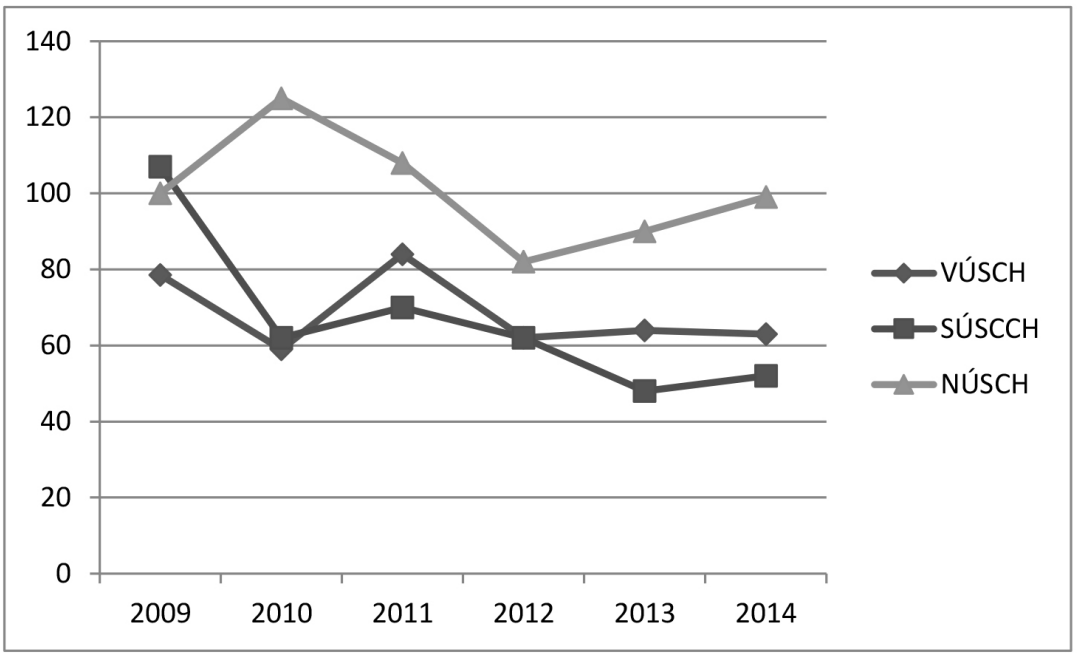




\section{Fig. 9: Development in the Turnover of Payables}

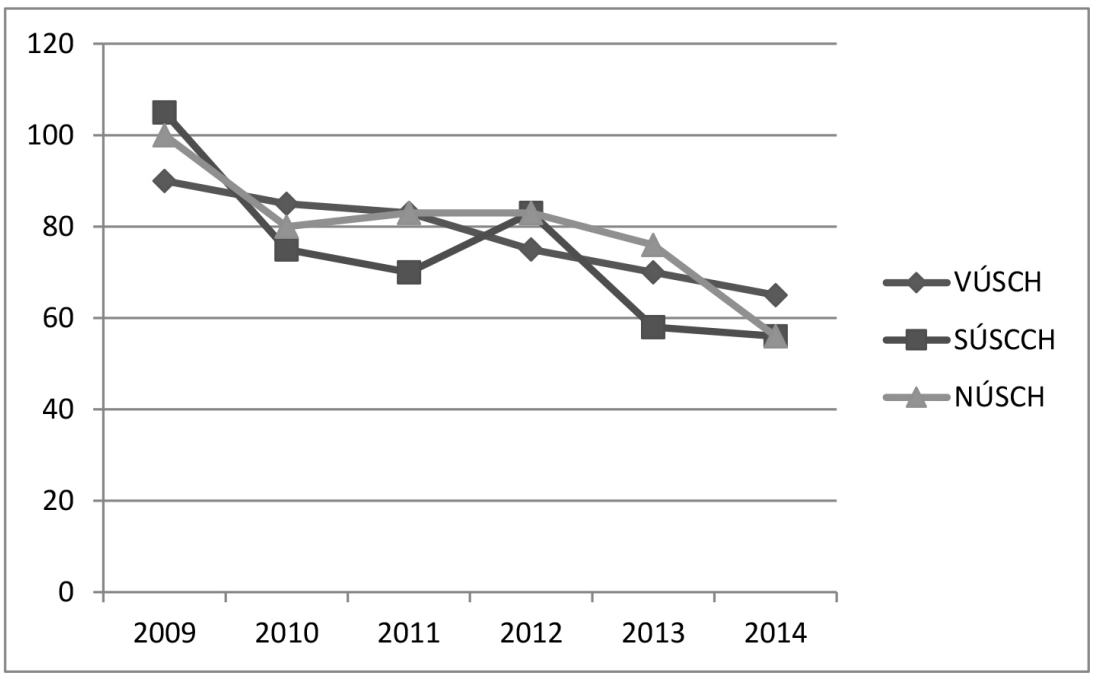

Source: own elaboration

development presented in Fig. 8. The results are revaeling the number of days untill the receivables are obtained out by the SHF. The lower the number of the days, the most efficient the TOR, enabling the SHF to be paid within the shortest period of time possible.

The longest period of time that had elapsed till the receivables are paid is expected by the $\mathrm{NúSCH}$, a.s., where the turnover of receivables falls between 83.1 and 125.2 days. The development of this indicator tended to reduce starting with year of 2010. However, since 2012 the time is becoming longer bringing the SHF days of inefficiency. At the SÚSCCH, a.s., receiavables are valued at the time of their inception in their nominal values whereas the receivables obtained by way of deposits into the Equity or those passed on are valued at the cost of acquisition the costs incurred with the actual costs incurred in the process of acquisition. Subsequently, the valuation at the given SHF is reduced by bad or questionable receivables. The tendency in the development of the TOR at the $v$ SÚSCCH, a.s. ranges within the time interval from 50.2 to 107.5 days and this continued to reduce starting with 2011 until 2013, a fact that is to be apprieciated as poitive. Over the last period investigated, in 2014 the turnover of receivables increased by 4.1 days. The $\mathrm{VúSCH}$, a.s. were expecting their receivables to be paid within the longest period of time in 2011, within 84.6 days. The development in TOR over the rest of the investigated period for the VúSCH, a.s where those of variable, falling within the interval from 58.4 to 84.6 days.

The last indicator evaluating activity is the Turnouver of Payables. The trend in the development of the TOP is illustrated in Fig. 9. Our analysis is concerned with the number of the days the investigated SHF can settle their payables. Here, the longer the period of payment, the more efficient the indicator.

By taking a look the graph above, we can see number of the day quite variable mostly showing a downard sloping tendency. Probably, it was the $\mathrm{NÚSCH}$, a.s. that had been found with the longest Turnover of Payables, in year 2009 (99.09 days) and in year 2012 (84.97 days). The shortest time of payments for payables were in 2014 (53.08 days) only.

At the SÚSCCH, a.s payables are valued at the time of their origin in thier nominal values and at a takover by their acquisition price. 
The longest TOP in the investigated SHF was in $v$ roku 2009 (102.9 days). The number of days during which the payables were paid back, however is gradually reducing until year 2012 , when this facility achieved a TOP of 82.2 days. In 2013 and 2014 the time of turnover in terms of the payables at the SÚSCCH, a.s. was shortening. The major condition of a stabile seller-buyer relation for the $\mathrm{VúSCH}$, a.s. will arrive on after having settled the payables from business contacts, in favour of the suppliers. In year 2009 the investigated SHF paying for its payables within the longest period of time, i.e. after 92.9 days. This number of days is reducing from year to year until 2014, when the VúSCH, a.s. is able to pay off its payables no later than in 62.6 days.

The finacial situation of the SHFs was evaluated using the Taffler model, Index IN 95, Index IN 99 and Index IN 05. The application of the Taffler model is conditioned by monitoring companies in the same branch. We adhered to this stipulation as the investigated specialized hospital facilities belong to the hospitals specialized in cardio-vascular diseases. When predicting the development of financial situation by way of the modified Taffler model, only the $\mathrm{NÚSCH}$, a.s. was rated over the entire period of investigation as a facility with positive rating, whereas both the SÚSCCH, a.s. and the spolu $s$ VúsCH, a.s were ranked among those facing bankruptcy. Another group of prediction models enable use of Indeces IN. In case of predicting financial development by way of IN Indeces, we have decided to apply them to the conditions of the Czech economy, the principles of operation are similar to those experienced in the Slovak economy. A disadvantage to these indeces is in the fact that they have been applied eclusively to the evaluation of development in industrial companies. The resulting values of the Index IN 95 and Index IN 05 are relatively high for the NÚSCH, a.s., a fact affected by the size of the costs of interests. Based on the evaluation of the results for predicting development by way of the Index IN 99, excluding the amount

Tab. 2: Prediction of financial development at SHFs by selected models

\begin{tabular}{|c|c|c|c|c|c|c|}
\hline \multicolumn{7}{|c|}{ TAFFLER'S MODEL } \\
\hline SHF/Year & 2009 & 2010 & 2011 & 2012 & 2013 & 2014 \\
\hline NÚSCH, a.s. & 0.37 & 0.46 & 0.46 & 0.44 & 0.51 & 0.62 \\
\hline SÚSCCH, a.s. & 0.01 & -0.04 & -0.06 & -0.02 & -0.03 & 0.03 \\
\hline VúsCH, a.s. & 0.15 & 0.14 & 0.17 & 0.15 & 0.17 & 0.19 \\
\hline \multicolumn{7}{|c|}{ INDEX of credibility IN 95} \\
\hline SHF/Year & 2009 & 2010 & 2011 & 2012 & 2013 & 2014 \\
\hline NÚSCH, a.s. & 699.31 & $-8,567.43$ & 2.26 & 2.09 & -308.13 & -762.05 \\
\hline SÚSCCH, a.s. & 1.18 & 1.67 & 1.68 & 1.92 & 2.15 & 1.80 \\
\hline VÚSCH, a.s. & 0.43 & 1.16 & 0.82 & 1.99 & 2.50 & 2.49 \\
\hline \multicolumn{7}{|c|}{ INDEX IN 99} \\
\hline SHF/Year & 2009 & 2010 & 2011 & 2012 & 2013 & 2014 \\
\hline NÚSCH, a.s. & -0.710 & -0.91 & -0.90 & -0.75 & -0.83 & -1.05 \\
\hline SÚSCCH, a.s. & 0.001 & 0.11 & 0.12 & 0.12 & 0.15 & 0.13 \\
\hline VÚSCH, a.s. & -0.140 & 0.06 & -0.02 & 0.17 & 0.22 & 0.23 \\
\hline \multicolumn{7}{|c|}{ INDEX IN 05} \\
\hline SHF/Year & 2009 & 2010 & 2011 & 2012 & 2013 & 2014 \\
\hline NÚSCH, a.s. & 254.77 & $-3,147.61$ & 1.39 & 1.29 & -111.48 & -276.39 \\
\hline SÚSCCH, a.s. & 0.63 & 0.85 & 0.88 & 0.98 & 1.09 & 0.93 \\
\hline VÚSCH, a.s. & 0.29 & 0.58 & 0.46 & 0.93 & 1.14 & 1.14 \\
\hline
\end{tabular}


of cost-related interests, we can state that all the investigated SHFs appear to be ripe for bankruptcy. The highest resulting values $(0.22$ and 0.23 ) were obtained in years 2013 and 2014 by the VÚSCH, a.s., which fall within the interval, when, by the interpretation of the results, the company is not generating value.

Summary of the results obtained by predicting the financial development at SHFs applying multi-dimensional models is recorded in Tab. 2.

\section{Discussion and the Conclusions from the Analysis}

Economical performance is primarily monitored by way of a set of concrete financial ratios that make up the essence of financial health on the part of the specialized hospital facilities as economic units (Curtis \& Roupas, 2009). When assessing efficiency using finacial rations, we have arrived at the following conclusions:

- When comparing the development in liquidity, it can be stated that all the three specialized hospital facilities are in good position in terms of solvency, i.e. from liquidity point of view they appear to be efficient.

- When assessing the results obtained from the evaluation of profitability, the SÚSCCH, a.s. turns out to be the most profitable over the investigated period. Demonstrating the highest average results in terms of the ROA, ROE and ROS are the very proofs of its efficiency. On the other hand, the lowest values of profitablility are seen at the $\mathrm{NUSCH}$, a.s., revealing the fact that the given facility is far from being efficient in utilizing its assets. The $\mathrm{NúSCH}$, a.s. is the worst from the owners' point of view, also presenting the lowest value of profitability per Euro when viewed from the ROSproving the poorest profitablility ratio of all the investigated SHPs.

- Based on comparing the results of indicators regarding activity, it can be stated that utilization of total asets both at the $\mathrm{NÚSCH}$, a.s. and the SÚSCCH, a.s. cannot be considered efficient as the vaues of TOA fail to reach the value 1 . The closest to this value were the results after aplying the DEA to the VúSCH, a.s. In view of TOR, the shortest average time is enjoyed by the $\mathrm{SÚSCCH}$, a.s. and the $\mathrm{VúSCH}$, a.s., thereby considering them as efficient. Conversely, the longest time spent waiting to recover the receivables is expected at the $\mathrm{NUSCH}$, a.s. Interestingly, the TOP is roughly identical showing a tendency to reduce.

We have performed prediction of the financial situation at specialized hospital facilities also by applying multi-dimesional models based on mathematical and statistical methods. Based on the aforesaid, we can state that the prediction models presented above are not suitable for assessing the efficiency of health facilities under the conditions valid in the Slovak republic (Tab. 2). Consequently, we have decided to suggest a new model applying discriminant analysis.

Applying the discriminant analysis helped select the coefficients of the disciriminatory function for the purpose of developing a new model that appears to be suitable for the evaluation of the facilities investigated. Then followed the comparision of the results from the prediction models and the those obtained from the suggested model of evaluating specialized hospital facilities.

\section{Model Design by the Way of the Discriminant Analysis}

The basis of the discrimination analysis consists in investigating the dependence of one qualitatative variable on several quantitavie variables. In the previous part of the text we have performed evaluation in via the DEA method, where, on the basis of comparing of the obtained results regarding the assessment of technical efficiency, we select two groups of the SHFs in question. Ranked into group 1 are those SHFs, wich failed to be efficient during the period of investigation, whereas group 2 will be made up of those, which still appear to be efficient throughout the period of investigation. The number of monitorings in the groups is illustrated in Tab. 3 .

As referred to by (Curtis \& Roupas, 2009), the set of financial ratios used as indicators are to be critically investigated, and after having combined the indicators, tools of efficient economy are to be suggested.

For the new model to be developed by way of the discirimination analysis, we make use of the financial ratios those of liquidity, profitability and activity, the development of which have already been analysed in detail. After determining the numbers of monitoring within the groups and on having defined the selected financial ratios, we perform a simultaneous test of agreement in the 
Tab. 3: Number of monitorings in the groups

\begin{tabular}{c|l|c} 
Group & & Number \\
\hline 1 & Method of DEA (inefficiency at least in one of the year monitored) & 2 \\
\hline 2 & Method of DEA (efficiency during the entire period of monitoring) & 1 \\
\hline Total & & 3 \\
\hline
\end{tabular}

Source: own elaboration

vectors of mean values, thereby contributing to the identification of the variables with the best discriminant feature. The agreements vectors of the mean values are illustrated in Tab. 4 and are related to the Return on assets, return on Equity, Return on Sales and Turnover of Assets.

By simultaneous testing the agreement at vectors of the mean values and the subsequent application of the disicriminant analysis, we select the coefficients of the discriminant function. The coefficient of constant is -3.436 and the coefficients of the rest of the indicators based on financial rations are illustrated in Tab. 5. Of importance for us are the coefficients as follows: - Return on Assets, return on Equity, Return on Sales, Turnover of Assets.

\section{Tab. 4: Simultaneous test of agreements at vectors of the mean values}

\begin{tabular}{l|c|c|c|c|c} 
& Wilks' Lambda & F & Df1 & Df2 & Sig. \\
\hline $\mathrm{x} 1$ = Immediate Liquidity & .965 & .586 & 1 & 16 & .455 \\
\hline $\mathrm{x} 2$ = Current Liquidity & .951 & .822 & 1 & 16 & .378 \\
\hline $\mathrm{x} 3=$ Overall Liquidity & .964 & .591 & 1 & 16 & .453 \\
\hline $\mathrm{x} 4=$ Return on Assets & .931 & 1.178 & 1 & 16 & .294 \\
\hline x5 = Return on Equity & .920 & 1.394 & 1 & 16 & .255 \\
\hline x6 = Return on Sales & .910 & 1.577 & 1 & 16 & .227 \\
\hline x7 = Turnover of Assets & .870 & 2.392 & 1 & 16 & .141 \\
\hline x8 = Turnover of Receivables & .983 & .276 & 1 & 16 & .606 \\
\hline x9 = Turnover of Payables & .999 & .013 & 1 & 16 & .909 \\
\hline
\end{tabular}

Source: own elaboration

\section{Tab. 5: Coefficients of the discriminant function}

\begin{tabular}{l|r} 
& \multicolumn{1}{|r}{ Function 1 } \\
\hline x1 $=$ Immediate Liquidity & 5.183 \\
\hline 2 $=$ Current Liquidity & -12.457 \\
\hline$x 3=$ Overall liquidity & 6.652 \\
\hline$x 4=$ Return on Assets & -0.971 \\
\hline$x 5=$ Return on Equity & -1.498 \\
\hline$x 6=$ Return on Sales & 2.588 \\
\hline$x 7=$ Turnover of Assets & 10.232 \\
\hline$x 8=$ Turnover of Receivables & 0.053 \\
\hline$x 9=$ Turnover of Payables & -0.025 \\
\hline Constant & -3.436 \\
\hline
\end{tabular}


The output of discriminant analysis is the discriminative function for the SHF, which is based on the financial or acconting statements for the period monitored and takes the form as follow:

\section{$Z=-3.436-0.971 \times \times 1-1.498 \times \times 2+2.588 \times$ $\times \times 3+10.232 \times \times 4$}

where:

$\mathrm{x} 1=$ net profit $/$ total assets

$\mathrm{x} 2=$ net profit $/$ equity

$\mathrm{x} 3=$ net profit $/$ sales

$\mathrm{x} 4$ = assets $/$ sales.

The next step for the suggested model is determining the centroids for the groups monitored, which were marked by numbers 1 and 2. Listed in Tab. 6 are the values of centroids, where we can see that for the SHFs marked with 1 the centroid is receiving the value of 1.79 , and for the group of SHFs marked with 2 this value is -0.512 .

Subsequently, by arithmetical mean value of the calculated values we arrive at the value of the dividing point, which is 0.639 . If the calculated value of the discriminative function > than the dividing point, then the predicted appurtenance is to group 2 and is marked as the positive. If the calculated value $<$ than the dividing point, then the predicted appurtenance is to group 1 , which is considered as appurtenance to bankruptcy.

Further step in the discrimination analysis is reviewing of the properly classified cases for the groups. Here in our case the model has ranked $88.9 \%$ of the cases, which means that we have achieved an $88.9 \%$ rate of success in determining the variable in this group of SHF.

Applying the discrimination analysis, we have suggested a new model for the SHFs in question, which appears to us as a working one. The calculated values of the indicator of discrimination function for the suggested model are recorded in Tab. 7 .

The discirminant function into which we have substituted the required values calculated from the finacial ratios is revealing the fact, whether the SHFs are rated highly or heading for bankruptcy. Based on the results in Tab. 7 we can see that during the period of monitoring, all the three SHFs appear to us as creditable, as the values calculated are larger than the dividing point, which is obtaining the value at the point of 0.639 .

\section{Conclusion}

Some phenomena affecting the overall efficiency cannot be expressed by financial indicators. They cannot be recorded into accounting standards, as being unable of reflecting nonfinancial aspects of company reality. This has also been confirmed by other authors (Kotane \& Kuzmina-Merlingo, 2012), maintaining that financial reports are the main sources of information about company performance, and basing on them the business activities and financial position of a company are evaluated.

\section{Tab. 6: Centroids (Functions at Group Centroids)}

\begin{tabular}{c|r} 
Group / Division & \multicolumn{2}{|c}{ Function 1 } \\
\hline 1 & 1.790 \\
\hline 2 & -0.512 \\
\hline
\end{tabular}

Source: own elaboration

\section{Tab. 7: Calculation of the indicators of the discriminant function for the suggested model}

SUGGESTED MODEL FOR ASSESSING SHF - Results of the discriminant function

\begin{tabular}{l|l|l|l|l|l|l}
\hline \multicolumn{1}{c|}{ SHF } & $\mathbf{2 0 0 9}$ & $\mathbf{2 0 1 0}$ & $\mathbf{2 0 1 1}$ & $\mathbf{2 0 1 2}$ & $\mathbf{2 0 1 3}$ & $\mathbf{2 0 1 4}$ \\
\hline NÚSCH, a.s. & 2.80708 & 2.69729 & 2.48616 & 2.70840 & 3.10674 & 3.67825 \\
\hline SÚSCCH, a.s. & 1.88002 & 2.45153 & 2.81840 & 3.27759 & 3.15477 & 4.01282 \\
\hline VÚSCH, a.s. & 2.36639 & 4.79267 & 5.81802 & 3.89001 & 4.66202 & 5.71189 \\
\hline
\end{tabular}


However, under conditions of contemporary economic development company management cannot rely only on the evaluation system of financial indicators in order to manage the company successfully. This is acknowledged by the fact that in our investigated facilities, where, on the basis of the comparing the assessment of technical efficiency by analyzing envelope data, we have confirmed that the SÚSCH, a.s. is the most effective of the investigated facilities, while the $\mathrm{NUSCH}$, a.s. being less effective, and the VÚSCH, a.s. considered as an inefficient facility.

Nevertheless, the primary documents and interviews with the patients lead us to conclude that the situation in terms of satisfaction with the services provided by in the facilities was quite the opposite. The most satisfied were the patients of the VúSCH, a.s., less satified those of the $\mathrm{NÚSCH}$, a.s. and the least satisfied were the patients of SÚSCH, a.s. Based on the aforementioned it follows that further research is to conducted focused on investigating nonfinnacial indicators of efficiency of health facilities.

\section{References}

Balík, P. (2012). Analýza regulačného rámca slovenského zdravotného sektora. Bratislava: Health Policy Institute.

Balík, P. (2013). Financovanie zdravotníctva - spôsoby a mechanizmy financovania. Zdravotníctvo - trhy, regulácia, politika. Health Policy Institute. Retrieved from http://hpi.sk/ hpi/sk/view/10495/financovanie-zdravotnictvasposoby-a-mechanizmy-financovania.html.

Baustein, M., Bartak, M., Janota, T., \& Rogalewicz, V. (2015). The cost of acute myocardial infarction treatment in the Czech Republic - The case of General University Hospital in Prague. In 2015 E-Health and Bioengineering Conference (EHB) (pp. 1-4). https://dx.doi.org/10.1109/EHB.2015.7391351.

Curtis, P., \& Roupas, T. (2009). Health Care Finance, the Performance of Public Hospitals and Financial Statement Analysis. European Research Studies, 12(4), 200-212.

Cylus, J., Papanicolas, I., \& Smith, P. (2016). Health system efficiency: How to make measurement matter for policy and management. World Health Organization.

Drummond, M. F., Sculpher, M. J., Claxton, K., Stoddart, G. L., \& Torrance, G. W. (2015). Methods for the economic evaluation of health care programmes. Oxford: Oxford university press.
Dlouhý, M., \& Barták, M. (2013). Mental Health Financing in Six Eastern European Countries. E\&M Ekonomie a Management, 16(4), 4-13.

Dlouhý, M. (2016). Medzinárodní srovnání výkonnosti zdravotnitví ve Visegradských zemích. Časopis lékařů českých, 5, 242-246.

Filko, M., Mach, J., \& Zajíček, J. (2012). Málo zdravia za vela peňazí: Analýza efektívnosti slovenského zdravotníctva. Bratislava: Inštitút finančnejpolitikyMinisterstvafinanciíSR. Retrieved from http://www.mfsr.sk/Load Document. aspx?categoryld=8789\&documentld=9367.

Gavurova, B., \& Soltes, M. (2016). System of day surgery in Slovakia: Analysis of pediatric day surgery discrepancies in the regions and their importance in strategy of its development. E\&M Ekonomie a Management, 19(1), 74-92. https://dx.doi.org/10.15240/tul/001/2016-1-006.

Hiligsmann, M. (2010). Evaluation économique de la prise en charge de l'ostéoporose (Doctoral dissertation, Université de Liège, Belgique). Retrieved from http://orbi. ulg.be/bitstream/2268/40956/1/Hiligsmann_ TheseDoctorat.pdf.

Ivlev, I., Kneppo, P., \& Bartak, M. (2014). Multicriteria decision analysis: a multifaceted approach to medical equipment management. Technological and Economic Development of Economy, 20(3), 576-589. https://dx.doi.org/10 .3846/20294913.2014.943333.

Jönsson, B. (2004). Changing health environment: the challenge to demonstrate cost-effectiveness of new compounds. Pharmacoeconomics, 22(4), 5-10. https://dx.doi. org/10.2165/00019053-200422004-00003.

Kamenský, G. et al. (2007). Koncepcia zdravotnej starostlivosti $v$ odbore kardiológia (pp. 49-108). Bratislava: Slovenská kardiologická spoločnost'.

Kotane, I., \& Kuzmina-Merlingo, I. (2012). Non-financial indicators for evaluation of business activity. European integration studies, 5, 213-219. https://dx.doi.org/10.5755/j01. eis.0.5.1099.

Khushalania, J., \& Ozcanb, Y. (2017). Are hospitals producing quality care efficiently? An analysis using Dynamic Network Data Envelopment Analysis (DEA). Socio-Economic Planning Sciences, 60, 15-23. http://dx.doi. org/10.1016/j.seps.2017.01.009.

Lovaš, L. (2001). Metódy výskumu pre verejnú správu. Košice: UPJŠ v Košiciach, Fakulta verejnej správy. 
Miller, P. (2009). An Introduction to Health Economic Evaluation. The NIHR RDS for the East Midlands / Yorkshire \& the Humber. Retrieved from https://www.rds-yh.nihr.ac.uk/ wp-content/uploads/2013/05/4_HealthEconomic-Evaluation-FINAL-2009.pdf.

Nichols, M. et al. (2012). European Cardiovascular Disease Statistics 2012. European Heart Network, Brussels. European Society of Cardiology, Sophia Antipolis.

NúSCH, a.s. (2015). Národný ústav srdcových a cievnych chorôb, a.s. Bratislava: $\mathrm{NúSCH}$, a.s. Retrieved from http://www.nusch.sk/.

Pažitný, P. et al. (2014). Modernizácia slovenských nemocníc. Základné rámce zdravotnej politiky na roky 2014-2020. Bratislava: Health Policy Institute.

SÚSCCH, a.s. (2015). Stredoslovenský ústav srdcových a cievnych chorôb, a.s. Banská Bystrica: SúsCCH, a.s. Retrieved from http://www.suscch.eu/page.php?13.

Soltes, M., \& Gavurova, B. (2015). Quantification and Comparison of Avoidable Mortality - Causal Relations and Modification of Concepts. Technological and Economic Development of Economy, 21(6), 917-938. https://dx.doi.org/10.3846/20294913.2015.110 6421.

Soltes, M., \& Gavurova, B. (2014). Identification of the Functionality Level of Day Surgery in Slovakia. Ekonomicky casopis, 62(10), 1031-1051.

Tesař, T., \& Foltán, V. (2006). Vybrané aspekty v rámci systému zdravotnej starostlivosti Slovenskej republiky. Farmakoekonomika a lieková politika, 2, 12-18.

Tunega, M. (2013). Širší pohlad na efektívnost' slovenského zdravotníctva.
Bratislava: Inštitút pre ekonomické a sociálne reform. Retrieved from: http://www.ineko.sk/ file_download/754.

VÚSCH, a.s. (2015). Východoslovenský ústav srdcových a cievnych chorôb, a.s. Košice: VúsCH, a.s. Retrieved from http://www.vusch.sk/.

Zavarská, Z. (2011). Zostavenie súboru klúčových indikátorov finančnej výkonnosti podniku. Acta Academica Karviniensia, 3, 194-208.

doc. Ing. Stanislav Szabo, PhD., MBA, LL.M. Czech Technical University in Prague Faculty of Transportation Sciences Czech Republic szabo@fd.cvut.cz

prof. Ing. Bohuslava Mihalčová, PhD. et PhD. University of Economics in Bratislava Faculty of Business Economy with Seat in Košice Slovakia bohuslava.mihalcova@euke.sk

Ing. Peter Gallo, PhD. University of Prešov Faculty of Management Department of Management Slovakia p.peter.gallo@gmail.com

Ing. Mariana Ivaničková, PhD. University of Economics in Bratislava

Faculty of Business Economy with Seat in Košice Slovakia mariana.ivanickova@euke.sk 


\title{
Abstract
}

\section{EVALUATING EFFICIENCY IN SPECIALIZED HOSPITAL FACILITIES - DEVELOPING THE MODEL BY WAY OF THE DISCRIMINANT ANALYSIS}

\author{
Stanislav Szabo, Bohuslava Mihalčová, Peter Gallo, Marianna Ivaničková
}

Currently, companies use for the diagnostic their performance different methods, parameters and indicators when the high current measurement and evaluation of effectiveness. Choosing the right key performance measures is to ensure the evaluation of the effectiveness with high recall and the possibility of subsequent influence and control very important. The main object of contribution is evaluating efficiency in hospital facilities specialized for patients suffering from cardio-vascular diseases, ailments that affect the largest group of people in living in Slovakia. This followed the discovery that the number of newborns in Slovakia suffering from congenital heart diseases has increased over the recent years, and in the period between 2002 and 2012 annually 451 children at an average are born with this congenital disorder. Another factor that prompted our research was that the diseases of the circulatory system are rated among the most frequent cause of hospitalization and mortality in Slovakia, as confirmed by the International Classification of Diseases or the ICD (the international equivalent of the Slovak $\mathrm{MKCH}-10$ ). Accordingly, people suffering from cardiovascular diseases belong to the most-frequently hospitalized patients. The third finding we have arrived at is the high level of consumption of prescription medicines by the Anatomical Therapeutic Chemical (ATC) Classification, again dominated by cardio-vascular diseases. The paper describes both the cardio-vascular diseases and the hospital facilities specialized in their treatment, assessing their efficiency in evaluating the major factors affecting them. The evaluation is carried out based on financial ratios and application of prediction models. The ouptut of this contribution consists in the evaluation of the efficiency of specialized hospital facilities (further only SHF) applying the DEA method and the evaluation of efficiency of the SHFs using financial ratios.

Key Words: Financial indicators, efficiency, model, hospital facilities.

JEL Classification: 115, P46, P47.

DOI: 10.15240/tul/001/2018-3-006 